\title{
ÉTICA DE COERÊNCIA DIALÉTICA
}

Carlos Cirne-Lima*

SINTESE - Dois são os grandes problemas de uma Ética geral hoje: Como passar de proposições descritivas para proposiçōes normativas? Qual o primeiro ou os primeiros princípios do Dever-ser? Propõe-se aqui um novo modelo de Ética. A fundamentação do Dever-ser - a primeira pergunta - se faz mudando o operador modal do princípio de não-contradição: "Não se deve predicar e não predicar", pois contradiçőes de fato existem, o que prova que elas não são impossiveis e sim indevidas. O primeiro princípio da Ética - esta é a proposta - consiste no próprio princípio de nảo-contradição, reformulado como Princípio da Coerência, válido para a Lógica, a Natureza e o Espírito.

PALAVRAS-CHAVE - Ética. Dever-ser. Princípio da Coerência.
ABSTRACT - There are two great problems in general ethics nowadays: How to proceed from descriptive to normative statements? What are the first principles of Ought (Sollen)? I propose here a new model for ethics. The foundation of Ought - the first question - is attained by changing the modal operator of the principle of non-contradiction: "One ought not to predicate and not to predicate", for contradictions do exist, which proves they are not impossible but rather undue. Ethics' first principle -such is the proposal- consists in the very principle of noncontradiction, recast as Principle of Coherence, valid to Logic, Nature and the Spirit.

KEY WORDS - Ethics. Ought. Principle of Coherence.

Fiz em Dialética para Principiantes' mais que uma interpretação e uma crítica ao sistema do Idealismo Absoluto de Hegel, esbocei também uma teoria nova, uma proposta de sistema que, com raízes profundamente fincadas na tradição neoplatônica, se inspira tanto no sistema de Hegel como nas críticas que foram levantadas contra este por Schelling, ${ }^{2}$ Kirkergaard, ${ }^{3}$ Trendelenburg, ${ }^{4}$ Nietzsche e tantos outros. Disse um claro e decidido Não à fragmentação da razão da assim chamada Pós-Modemidade e tentei levantar, de novo, ao arrepio do Zeitgeist, a bandeira da Filosofia como Sistema, usando para isso operadores lógicos mais

* Professor do Programa de Pós-Graduação em Filosofia da Faculdade de Filosofia e Ciências Humanas da PUCRS.

1 CIRNE-LIMA, C., Dialética para Principiantes, Porto Alegre: Edipucrs, 1997.

2 Cf. especialmente as preleçōes de Schelling em Munique, dos anos 1833 e 1834, Zur Geschichte der neueren Philosophie, SCHELLING, F. W. J., Ausgewähite Schriften, Frankfurt am Main: Suhrkamp, 1985 , vol.4, p. 417ss.

f. KIERKEGAARD, S., Philosophische Brocken, idem, Unwissenschaftliche Nachschrift zu den Philosophischen Brocken, in: Gesammelte Werke, ed., München: Hirsch/Gerdes, 1991. Vol. 10. Cf. também THULSTRUP, N., Kiekergaards Verhältnis zu Hegel. Forschungsgeschichte, Stuttgart: Kohlhammer, 1969.

4 TRENDELENBURG, A., Logische Untersuchungen, 2 vol., Berlim, 1940.

\begin{tabular}{|l|l|l|l|l|l|}
\hline VERTTAS & Porto Alegre & v. 44 & n. 4 & Dezembro 1999 & p. 941-964 \\
\hline
\end{tabular}


fracos que os tradicionalmente empregados e evitando, desde o primeiro começo, identificar Filosofia com conhecimento meramente a priori. Este dogma do a priori, quase nunca examinado criticamente, reduziu toda a Filosofia a uma ciência formal, a ser construída de maneira totalmente independente do conhecimento sensível, e a esvaziou, assim, de todo conteúdo contingente e histórico. Esta redução da Filosofia, a meu ver ilegítima, a um mero a priori a empobreceu grandemente e a conduziu, em nosso século, a teorias que retomam, sim, a História em sua contingência - o que é ótimo - mas que abandonam - o que é péssimo - a Filosofia como Sistema, como uma Totalidade em que todos os outros saberes harmoniosamente se inserem, em que os saberes particulares são legitimados pela sua coerência uns com os outros e com o saber universal do Sistema do qual são partes constitutivas. Assim como no universo real cada átomo é determinado por todos os outros, isto é, pela totalidade do que existe no universo, assim também na ciência, na ordem lógica, Filosofia só merece este nome se e quando se estrutura como Sistema. Neste sentido tanto os neoplatônicos antigos, como Plotino, Proclo e Agostinho, como os modernos, como Espinosa, Fichte, Schelling e Hegel, tinham toda a razão. Errados estamos nós quando cedemos à tentação pósmodema e aceitamos a fragmentação da Razão, sim, até nos orgulhamos disso. Trabalhamos apenas com subsistemas e afirmamos que não existe um sistema universal - a Filosofia como Sistema - que abranja e abarque todos os subsistemas. Ora, essa proposição, a saber, que não existe uma proposição ou princípio que seja válido para todos os subsistemas é, ela mesma, uma contradição que explode quando a formulamos. Contra essa corrente dominante em nosso Zeitgeist elaborei o projeto de sistema apresentado em Dialética para Principiantes, onde há - entre outras coisas só aparentemente mais importantes - um pequeno capítulo, o segundo da terceira parte, ${ }^{5}$ que versa expressamente sobre Ética. O leitor atento, entretanto, percebe que o capítulo mencionado é apenas uma explicitação sucinta de uma idéia central que perpassa todo o projeto de sistema, do começo até o fim, ou seja, que perpassa todo o livro.

O projeto de sistema ali proposto é, todo ele, e por inteiro, uma teoria do Dever-ser e, neste sentido, uma Ética. A Lógica e a Ontologia dialéticas que ali proponho têm como operador modal primeiro e mais importante não a necessidade lógica e/ou metafísica da tradição filosófica dos últimos séculos e, sim, um operador modal mais fraco, que é aquela necessidade que pressupõe e permite a existência de eventuais contrafatos, ou seja, a necessidade deôntica do Dever-ser. 0 Dever-ser é uma necessidade, sim, mas um tipo de necessidade que pressupõe e implica a possibilidade de que existam contrafatos, isto é, pressupõe que ações eticamente más continuam sendo algo passível de existir, algo possivel, e algo que muitas vezes de fato existe. Com este conceito amplo de Dever-ser a Ética é ali concebida e desenhada como algo mais universal e mais abrangente que as Éticas tradicionais. Na tradição, Ética é um subsistema dentro do sistema geral da Filosofia, é apenas uma disciplina dentro do corpus philosophicum, é um conjunto pequeno dentro de um conjunto maior, é só uma parte dentro de um todo maior. No projeto de sistema por mim proposto, o Dever-ser da Ética é o operador modal

5 CIRNE-LIMA, C., ibidem p.169-201. 
mais amplo e mais universal, o Dever-ser é o Todo, que dentro de si abrange, como partes, tudo o mais; Lógica e Ontologia são, penso eu, subsistemas dentro do grande conjunto da Ética Geral que se constitui através do operador modal do Dever-ser, como o travejamento básico de toda a Primeira Filosofia.

Tentarei, nas páginas que seguem, esboçar à maneira dos Éticos contemporâneos as linhas gerais e a estrutura da Ética da Coerência Dialética, deixando em segundo plano, como que esmaecida, a universalidade do Projeto de Sistema que desenhei em Dialética para Principiantes.

\section{Posição do problema}

Uma Ética Geral hoje, em todos os autores, lida com dois problemas centrais e inúmeras questões que, embora relevantes, poderiamos classificar de acessórias. Os dois problemas centrais são: 1) a passagem de proposições descritivas para proposições normativas, ou seja, uma fundamentação do Dever-ser que evite a falácia naturalista; 2) a formulação de um ou dois (ou três, ou quatro) primeiros princípios éticos que, se corretamente aplicados a uma situação concreta, permitam dizer o que é eticamente certo, o que é errado. Além destas duas questões, que são as fundamentais, várias outras se colocam. ${ }^{6} \mathrm{~A}$ mais importante delas refere-se a um problema crucial de nossos tempos, à Ecologia: Como construir uma Ética que, vigendo entre os homens e para os homens, fundamentada exclusivamente na dignidade da pessoa humana, mostre e justifique as obrigações ecológicas que hoje ninguém mais nega como sendo parte importante de nosso Deverser? Além disso, como construir uma Ética que, sendo universal e, por isso, necessariamente formal, possa ter conteúdos materiais? De onde vêm estes conteúdos materiais? Como conciliar, em tais Éticas, o a priori e o a posteriori? E ainda, como conciliar a validade universal de princípios éticos e a pluralidade legítima das muitas culturas? Como evitar o rigorismo? Por que e como uma determinada norma ética, por exemplo, não mentir, na maioria dos casos é válida e legítima, mas em alguns casos se inverte e se transforma em seu contrário, determinando que nestes casos o ético consiste em mentir? Ou, em outro exemplo, por que o preceito ético Não matarás em certos casos de legítima defesa é suspenso e se inverte no imperativo igualmente ético Neste caso deves matar? Por que a Ética não trata de recompensa e castigo, pelo contrário os desvirtua? São recompensa e castigo apenas categorias da Pedagogia e do Direito? Mas, se recompensa e castigo não estão enraizados na Ética, como podem entrar de maneira legítima na Pedagogia e no Direito? Qual a ligação entre Ética e Direito? Já que ambas as disciplinas têm no Dever-ser sua categoria central, há princípios que sejam comuns a ambas? Estas e muitas outras questões precisam ser respondidas por qualquer projeto de Ética Geral que se queira minimamente satisfatório. Muitas são as perguntas e há muitas tentativas de resposta que, como sabemos, não são satisfatónias. A primeira pergunta daquelas que foram formuladas acima, aquela sobre a maneira como o Dever-ser existente na Ecologia está enraizado na Ética Geral, embora sendo da maior relevância, está até hoje sem resposta.

- OLIVEIRA, M. A., Ética e Racionalidade Modema, São Paulo: Loyola, 1993; idem, Ética e Sociabilidade, São Paulo: Loyola, 1993; idem, Ética e Práxis Histórica, São Paulo: Ática, 1995. 
O primeiro grande problema de toda Ética Geral, como acima exposto, consiste na passagem de proposiçōes descritivas para proposiçőes normativas, ou, dito de outra forma - mais correta e mais ampla - consiste em uma fundamentaçăo teórica do Dever-ser que evite a falácia naturalista tảo bem caracterizada por Hume e, mais recentemente, por Moore. Proposiçőes normativas năo são algo que possa ser dado ou medido pela experiência sensivel; no mundo sensivel as coisas são o que são e como săo, nåo existindo af nenhum Dever-ser que possa ser percebido. Mas, se năo formamos o conceito de Dever-ser a partir da experiência sensivel, se esta năo é critério do mesmo, de onde vem o Dever-ser? Se ele não vem do mundo sensivel e a posterion, significa isso que ele é algo a prion? $\mathrm{E}$ isso pode ser demonstrado? Ou ao menos mostrado? O segundo grande problema de uma Ética Geral consiste em formular e justificar o grande princípio ou, se forem mais de um, os primeiros princípios dos quais todas as outras normas e leis derivam e nos quais se fundamentam. Ambos os problemas, é obvio, estăo entrelaçados e so podem ser tratados em conjunto. As questōes que acima formulei como acessórias, inclusive aquela sobre a Bcologia, se resolvem - ou, como acontece na maioria dos casos, nåo se resolvem - a partir desses primeiros princípios.

Platăo responderia que os primeiros princípios da Ética se justificam por serem particularizaçōes das grandes leis que regem o Universo cósmico. As mesmas leis cósmicas que regem os astros, a natureza e todo o universo regem também as partes da alma do homem; as virtudes correspondem às partes da alma e é por isso que as leis expressas por essas virtudes são éticas. A eticidade das leis se baseia na ontologia das partes da alma. Näo haveria ai, já em Platāo, uma falácia naturalista? Fundamentar a eticidade das virtudes na estrutura das partes da alma, fundamentar as leis éticas em leis da natureza, não é justamente nisso que consiste a falácia naturalista? Muitos, hoje, diriam que sim: Platão incorre na falácia naturalista, e acrescentariam Amicus Plato, magis amica veritas. Ver-se-á, mais abaixo, que eu pessoalmente näo compartilho dessa opiniăo e não interpreto Platão desta maneira. Mas que a questão da falácia naturalista deve ser colocada também com referência à Ética de Platão, não há đúvida, sim, deve.

Aristóteles, ao contrário, como que antecipando as objeçōes de Hume e de Moore, distingue e separa cuidadosamente proposiçōes descritivas e proposiçöes normativas. A Ética, em Aristóteles, é não só um livro e uma disciplina separados mas um subsistema da Filosofia todo especial porque atua com um operador modal distinto do das outras disciplinas filosóficas e que é próprio e exclusivo dele, o Dever-ser ínsito nas virtudes. Aristóteles antecipa Kant ao separar clara e rigorosamente a razão prática da razão teórica. Phrónesis e epistéme são reinos diferentes, separados, e atuam com operadores modais diversos. Mas feita essa distinçäo e separação, coloca-se de novo o problema: Como se justifica este Deverser ínsito nas virtudes? Aristóteles começa dizendo que a justificação e o critério do Dever-ser consistente na habitualidade da virtude, ou seja, na tradição. Esta resposta, como regra prática, é muitas vezes válida, é boa, e até hoje todos estamos de acordo sobre a importância e o conteúdo ético da tradição. Mas a tradiçăo nem sempre é princípio e critério da eticidade. O próprio Aristóteles já sabia disso. 
Há tradiçōes que são eticamente más. Qual, entăo, o princípio e critério do Deverser? A mesótes, responde Aristóteles,' o meio termo entre os extremos que devem sempre ser evitados. Mas ele mesmo, Aristóteles, algumas linhas mais adiante, observa que o meio termo nem sempre está exatamente no meio. Assim a virtude da coragem, segundo ele, não está bem no meio caminho entre a covardia e a temeridade; ela está mais perto da temeridade do que da covardia. Mas se a mesótes não está sempre no meío, se ela năo é a justificação e o critério último, qual é o primeiro-último principio da Ética? Aristóteles responde: o orthòs lógos, a reta razão que aflora no discurso bem conduzido. Orthós lógos significa ambas as coisas, tanto a reta razảo como o discurso bem conduzido. Significa ambas as coisas ao mesmo tempo? Talvez, uma tal interpretação aproximaria Aristóteles dos modernos defensores da Ética do Discurso. Mas - ponhamos ênfase nisso - a questão sobre a passagem legitima e justificada de proposiçöes descritivas para proposições normativas continua sem soluçăo bastante. $O$ que faz Aristóteles? 0 mesmo que mais tarde Kant fará: separar clara e decididamente a razão prática da razão teórica. Mas, mesmo isso feito e pressuposto, o problema continua: Como se fundamenta o primeiro principio ético, a primeira proposiçăo normativa? Aristóteles não nos dá resposta que seja bastante, nem Tomás de Aquino, nem McIntyre me perdoe - os aristotélicos da Idade Média e da Modernidade. A razão prática fica separada, sim, da razão teórica, o que parece ser bom, mas continua sem fundamentaçäo satisfatória, o que certamente não é bom.

Kant dá um grande passo a frente. Além de separar a razão prática da razão teórica, Kant tenta fundamentar o Dever-ser através de seu método transcendental. O método transcendental é regressivo e se fundamenta no antigo princípio de lógica modal $A b$ esse ad posse valet illatio, Do existir para o poder-ser a ilação é válida. Existem de fato juízos sintéticos a prioni que são verdadeiros; logo, é válido concluir que tais juizos sintéticos a priori verdadeiros possam, em princípio, existir. Kant faz uma sofisticaçăo maior da velha ilaçăo modal; como que antecipando lógicas modais contemporâneas como a S5 de Lewis, ele faz a ilação do fato contíngente para sua possibilidade enquanto esta é necessária. Se algo de fato existe, entåo existem também as condiç̧̋es necessárias de possibilidade deste fato. E estas condiçōes necessárias de possibilidade antecedem ontologicamente o fato, elas vem antes dele e, neste sentido, são a priori, são transcendentais. Na razão teórica, as formas de espaço e tempo e as categorias do entendimento são a priori, e por isso válidas independentemente do conhecimento sensivel que vem de fora, que é a posterioni. Na razåo prática, o Imperativo Categórico è a condição necessária de possibilidade do assim chamado fato da razão, o fato de que todos os povos em todos os lugares e todos os tempos possuirem alguma forma de Deverser. Kant tenta, através do método regressivo, fundamentar o Dever-ser, o Imperativo Categórico, como um princípio que é a priori, ou seja, transcendental, e, por isso, universalmente válido. A Filosofia contemporånea, que analisou logicamente

7 ARISTÓTELES, Btica a Nicómaco, in: obra completa em 23 volumes, ed. Loeb Classical Library: Cambridge Mas. e London, 1980. 
a questão dos assim chamados argumentos transcendentais, ${ }^{8}$ chegou a uma conclusão bem clara: há neles sempre uma premissa empírica. $\mathrm{E}$ aqui se formula uma das grandes objeções contra Kant: em havendo uma premissa empírica, a conclusão é sempre tão fraca como a mais fraca das premissas. Ora, havendo uma premissa meramente descritiva, toda a argumentação cai por terra, pois a conclusão não é uma proposição normativa e sim uma proposição descritiva, não é um Dever-ser mas sim um simples Ser. Façamos, porém, uma contra-argumentação. 0 raciocínio de Kant se constitui em falácia naturalista? A rigor, não. Há um elemento naturalista nele, não se pode negar, o fato de que há juízos sintéticos verdadeiros, na razão teórica, e o fato da razão, na razão prática. Há um certo naturalismo, sim, mas não há falácia, pois o argumento de Kant se baseia num princípio de lógica modal universalmente aceito: $A b$ esse ad posse valet illatio. Há uma premissa empírica, sim, isso não obstante, Kant, os kantianos e os especialistas em Lógicas modais contemporâneas vão legitimamente em frente, Kant fundamentando o Imperativo Categórico, os Lógicos elaborando uma rede de proposições necessárias a partir do assim chamado Axiom of Possibilitation,' que contém uma premissa empírica: $S e p$, então a possibilidade de $p$. Isso não é falácia nenhuma, este é o mais importante axioma de toda e qualquer lógica modal. $\mathrm{E}$, indo mais adiante, no sistema S5, vai afirmar-se a necessidade desta possibilidade. Isto é Lógica modal contemporânea, isto é o núcleo duro do argumento e do método de Kant. ${ }^{10}$ É Kant quem tem razão? Ou Hume e Moore?

Apel ${ }^{11}$ e Habermas, ${ }^{12}$ na Ética do Discurso, tentam dar um passo em frente. Eles não pressupõem, na fundamentação da Ética, um fato da razão, como Kant fez, porque querem evitar a objeção de que a conclusão não pode ser mais forte que a mais fraca das premissas. Apel redescobre, aqui, uma antiga e elegante forma de argumento indireto: a demonstração de uma proposição ou princípio pela redução de seu contrário a uma contradição performativa. Este tipo refinado de reductio ad absurdum, é modemizado por Apel através de um tipo específico de contradição, a contradição performativa. Quem discursivamente nega o discurso que está em curso entra em contradição: 0 ato de fala desmente 0 conteúdo falado. Assim começa Apel a fundamentação de sua Ética. Na terminologia de Habermas: ${ }^{13}$ o princípio D, o princípio do Discurso, não pode ser negado sem au-

- Cf. especialmente NIQUET, M., Transzendentale Argumente; Kant, Starwson und die sinnkritische Detranszendentalisierung, Frankfurt am Main: Suhrkamp, 1991, onde se encontra um belo resumo da discussão havida e abundantes referências bibliográficas.

- Cf. HUGHES, G.E./ CRESSWELL, M.J., An Introduction to Modal Logic, London: Methuen, 1972, especialmente p.22ss, p.28.

11 C. PALMER, H., The Transcendental Fallacy, in: Kantstudien 74 (1983) p. 387-404

Cf. especialmente APEL, K.-O., Die Transformation der Philosophie, 2 vol. Frankfurt am Main: Suhrkamp, 1976; idem, Diskurs und Verantwortung. Das Problem des Übergangs zur postkonventionellen Moral, Frankfurt am Main: Suhrkamp, 1988; idem, Auseinandersetzungen in Erprobung des transzendental-pragmatischen Ansatzes, Frankfurt am Main: Suhrkamp, 1998.

Cf. especialmente HABERMAS, J., Moralbewusstsein und kommunikatives Handeln, Frankfurt am Main: Suhrkamp, 1983; idem, Theorie des kommunikativen Handelns, Frankfurt am Main: Suhrkamp, 1981; idem, Faktizität und Geltung. Beiträge zur Diskurstheorie des Rechts und des demokratischen Rechtsstaats, Frankfurt am Main: Suhrkamp,1992. mas: 60 anos, Tempo Brasileiro, 98 (1989) p. 23-78. 
tocontradição. Logo, o Princípio $\mathrm{D}$ é válido. A partir do Princípio $\mathrm{D}$, que se realiza na roda do discurso, Apel e Habermas justificam, então, o Princípio U, o Princípio da Universalização, que é, em suma, o Imperativo Categórico de Kant. Pois, na roda do discurso, só valem razöes que possam ser universalizadas por todos. Ser passivel de universalizaçäo toma-se, assim, o grande princípio de toda Ética do Discurso. Com a fundamentação destes dois pnincípios, $\mathrm{D}$ e U, feita através da contradiçăo performativa, Apel e Habermas julgam ter feito uma passagem legítima de proposições descritivas para normativas, evitando a falácia naturalista. A objeção que contra a Ética do Discurso se levanta é que estes dois princípios, ambos formais e procedimentais, não bastam; para definir na roda do discurso o que é certo e o que é errado é preciso utilizar pelo menos um terceiro principio que consiste nas razōes que são postas na roda do discurso. As razões apresentadas precisam ser razões e não apenas bobagens. Ora, isso não é mais algo formal e meramente procedimental; com isso a Ética abandona o formalismo de Kant e adentra outro reino. Apel e Habermas concedem expressamente que devem ser apresentadas razōes, Gründe, mas não admitem que isso se constitua num terceiro princípio. Năo admitem, por igual, que isso os faz abandonar o modelo formal da Ética kantiana e o modelo meramente procedimental da própria Ética do Discurso.

As recentes tentativas de Ernst Tugendhat" - um pensador que em seus outros escritos prima pela clareza - de fundamentar o Dever-ser da Ética Geral não me parecem nem claras nem convincentes. A proposta de solução de Tugendhat, que evidentemente ainda está lutando como que corpo a corpo com o problema, me parece oscilar entre um naturalismo disfarçado e um contratualismo envergonhado. Mas só à medida que houver uma depuraçăo maior dos argumentos de Tugendhat é que poderemos nos posicionar com firmeza, seja a favor, seja - o que julgo mais provável acontecer - contra.

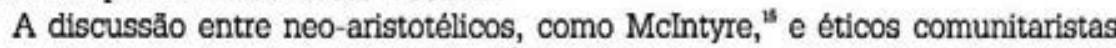
(comunitarians), como Charles Taylor, " fol extremamente fecunda. Os livros de McIntyre e de Taylor, exuberantes em erudiçăo e fineza de argumentos, não podem ser suficientemente recomendados a quem queira estudar a fundo o problema da fundamentaçåo da Ética Geral. Năo obstante, a resposta dada ao problema đa justificação do Dever-ser e de seus primeiros princípios năo me parece suficiente. Nem ao mero fato de algo pertencer à tradiçäo (McIntyre) nem à identidade cultural de um Eu ampliado (Taylor), são, por si sós, argumento bastante para justificar e fundamentar uma Ética Geral.

Vittorio Hoesle, em seu erudito e copioso livro sobre Ética e Politica," segundo minha opiniảo, năo acerta no alvo. Primeiro, porque pressupöe uma Natureza

" TUGENDHAT, E., Vorlesungen tuber Ethik, 3, edit, Frankfurt am Main: Suhrkamp, 1995 (em portuguess, Petrópolis: Vozes, 1997 ).

15 Cf. MCINTYRB, A., After Virtue, London: Duckworth, 1981; idem, Whose Justice? Which Rationality?, London: Duckworth, 1988.

to TAYLOR, C., Sources of the Self. The Making of the Modern Identity, Cambridge Mas:- Harvard Univ. Press, 1989.

1 HOESLB, V., Moral und Politik. Grundlagen einer politischen Ethik für das 21. Jahrhundert, München: Beck, 1997. 
deterministica, que em última análise não permite nem a escolha a ser feita pelo livre-arbítrio nem a responsabilidade a ela correspondente. Segundo - e isso decorre do primeiro ponto - porque o Dever-ser, no quadro do determinismo pressuposto, não pode ser corretamente pensado $e, a$ fortion, não pode ser fundamentado. Pensar a liberdade como necessidade, como Hoesle faz, apoiando-se expressamente em Leibnitz e Hegel, é, em minha opiniāo, enveredar, desde o primeiro começo, por um caminho errado. Uma tal liberdade e uma tal responsabilidade näo me convencem; aqui sou eu que digo Amicus Victonius, magis amica veritas.

\section{Gênese e justificaçäo do dever-ser}

Em minha opinião, a colocação do problema de fundamentação da Ética Geral como sendo a justificação da passagem de proposiçôes descritivas para proposições normativas já é um erro, e como já dizia Tomás de Aquino no começo do $D e$ Veritate e, hoje, dizem os defensores das teorias sobre o caos deterministico, um pequeno erro no começo leva a um grande erro no fim (parvus error in initio, magnus in fine). Sabemos todos que problemas mal colocados quase sempre se transformam em problemas insolúveis. Insolúveis porque e enquanto mal colocados. Quem nos garante a verdade dos pressupostos tácitos feitos pela colocação tradicional do problema? Quem nos garante que nos movimentamos, no dia-a-dia, com certeza e pretensão de verdade, num mundo de proposiçőes meramente descritivas? Quem nos garante, então, que é a partir deste mundo de proposições descritivas que se deva fundamentar o mundo das proposições normativas? 0 discurso meramente descritivo possui, por acaso, uma prioridade, seja de certeza, seja de verdade, seja de racionalidade? Concedo uma coisa: Quem admite e defende a prioridade das proposiçōes descritivas nos três sentidos acima explicitados tem que aceitar a colocaçăo tradicional do problema e perguntar como, a partir do que é prius em certeza, verdade e racionalidade, pode construir uma ponte para chegar ao reino das proposições normativas. E, em minha opinião, nunca o fará corretamente. Proponho um caminho diferente. Abandonemos a colocação tradicional e principalmente suas premissas tácitas - em minha opinião, falsas - a saber, a de que haja um prius em certeza, verdade e racionalidade das proposiçōes descritivas. Proponho que façamos, já aqui, uma inversảo, que aliás corresponde bem mais à realidade fenomenal em que vivemos e nos movimentamos: 0 reino das proposiçőes normativas é um conjunto maior, dentro do qual se encontra, menor e mais pobre, o conjunto das proposiçōes descritivas. Nossas proposiçỏes, no dia-a-dia concreto, såo normativas, isto é, cheias de valores e desvalores; é claro que elas contêm também elementos descritivos. Mas a proposição meramente descritiva no sentido estrito, a assim chamada objetividade total, é uma postura posterior, derivada, secundária, difícil senão impossivel de conseguir, que consiste em, partindo das proposiçöes normativas e valorativas do dia-a-dia, fazer um tal recorte que, na medida do possível, as valoraçóes sejam deixadas de lado, de sorte que o que resta, depois do recorte feito, é uma proposição meramente descritiva. O descritivo, nesta visão, se engendra por recorte e por empobrecimento - por abstração - das proposições concretas de nosso dia-a-dia. Se quisermos falar de um prius de certeza, de verdade e de racionalidade devemos consi- 
derar nossas proposições concretas do dia-a-dia, que săo sempre valorativas, exceto quando, num esforço especial, fazemos um recorte que separa o meramente descritivo da riqueza de nossas proposiçōes realmente originais. Não se trata, assim, na questão central da fundamentação do Dever-ser, de justificar a passagem de proposiçōes descritivas para normativas, como se as primeiras fossem mais certas, mais verdadeiras e mais racionais. Muito pelo contránio, nossas certezas, verdades e racionalidade primeiras consistem em expressões e proposiçóes recheadas tanto de objetividade a ser descrita como de valoraçőes feitas sobre isso. Isto aceito, a reta colocação do problema näo consiste em justificar a passagem de proposições descritivas para normativas - a nigor, deveria ser exatamente o contránio - mas de justificar o Dever-ser ínsito em nossas expressōes e proposições primevas, que além de descritivas säo desde sempre normativas. Esta posição, ao invés de facilitar a soluçăo do problema, à primeira vista parece dificultá-la ainda mais. Como justificar proposiçōes normativas em seu Dever-ser, se não podemos pressupor como ponto de partida nem mesmo as proposições descritivas? Ao reformular o problema, que mostramos estar mal colocado, ao invés de facilitar, dificultamos a solução. Ou não? Não, agora podemos de uma maneira simples, clara e, em minha opinião, convincente, justificar em sua raiz o Dever-ser como o grande operador modal não só da Ética mas de toda a Filosofia. E neste ponto - como sói ocorrer em todos os problemas que são realmente centrais voltamos a Platão e a Aristóteles, voltamos ao primeiro princípio do ser e do pensar, ao Princípio de Não-Contradição, ao livro Gamma da Metafisica.

O Princípio de Não-Contradição foi formulado por Aristóteles na seguinte maneira: "É impossivel predicar e não predicar o mesmo predicado do mesmo sujeito sob o mesmo aspecto e ao mesmo tempo". 19 Este é o primeiro princípio do pensar e do falar que, quando negado, ressurge das próprias cinzas e se reafirma de novo. Quem o nega fica reduzido ao estado de planta, sem pensar e sem falar. Todos nós conhecemos e - não é temerário dizê-lo - todos nós aceitamos o Princípio de Não-Contradição como verdadeiro e universalmente válido.

Isso não impediu Newton C. da Costa" e alguns outros lógicos de construir Lógicas paraconsistentes nas quais aparecem negaçöes fortes e negaçöes fracas, de tal maneira que - aparentemente - o Principio de Não-Contradiçâo não vale sempre. Nem mesmo em Lógica formal. Não é exato. O que Newton C. da Costa nos mostrou é que o Principio de Não-Contradição permite e exige várias formas de negação, como que melodias em torno de vários tipos de não-contradição.

Animado e inspirado pela coragem intelectual de Newton, que vim a encontrar pessoalmente só muitos anos depois, debrucei-me longa e meticulosamente sobre o livro Gamma em geral e, especificamente, sobre a formulaçäo aristotélica do Principio de Não-Contradiçăo. Descobri algo importante e fundamental, mas que é muito simples, quase óbvio, e que nunca é dito por ninguém: Aristóteles errou ao formular o Princípio de Não-Contradição. O grande inventor da Lógica

14 ARISTOTBLES, Metafisica, In: Aristotle in twenty-three volumes, vol. XVI, ed. Loeb Classical Library, Cambridge Mas.: Harvard Univ.Press, 1980, p.160, Meta. 1005 b 19 ss.

19. DA COSTA, N.C., Sistemas formais paraconsistentes, Curitlba: Editora UFPR, 1993. 
formal, o descobridor do sistema de silogismos, o primeiro autor de uma tabela de operadores modais, errou ao dizer que a contradição é impossível, adýnaton. ${ }^{20} \mathrm{~A}$ contradição é algo errado, é algo indevido, é algo irracional; a contradição é uma bobagem, pois quem diz e se desdiz é um tolo. Mas impossivel no sentido estrito, adýnaton, a contradição não é. Prova? Basta dizer ou escrever "p e não-p" e aí temos uma contradição: ela existe, ela está aí, escrita. Mas ela é um erro, uma bobagem, um non-sense, um atentado contra a racionalidade. Certo. Mas erros, bobagens, atentados contra a racionalidade, assim como contradições de vez em quando existem. $\mathrm{E}$ o que existe não é impossivel. $\mathrm{O}$ impossivel não existe nunca nem pode existir, como é o caso de um círculo real que seja quadrado. Escrevemos, sim, a contradição "círculo quadrado" (trata-se de uma contradictio in adjecto); este tipo de contradição existe no mundo do pensar e do falar, mas um círculo existente no mundo real, por exemplo na ponta de um poste ou mesmo em um desenho real, jamais é quadrado. $\mathrm{O}$ círculo quadrado como contradição falada e escrita existe e é possível, como realidade realmente existente, não. A contradição às vezes, muitas vezes, existe. Mas, objetar-se-á com toda a razão, ela é uma tolice, ela fere a racionalidade, ela é um grande erro, ela é indevida e imprópria. Certo, certíssimo. A contradição não deve ser, só que às vezes ela, embora não devesse existir, de fato existe. Ela não devia existir exatamente porque ela é uma bobagem que fere a racionalidade, porque ficamos dizendo e nos desdizendo, porque a contradição nos faz de bobos. Mas que ela às vezes existe, existe; isto ninguém nega. Ora, o que existe não é impossivel. Logo, a contradição não é impossível. O operador modal é impossivel foi aqui usado por Aristóteles com impropriedade. O que Aristóteles queria dizer tem que ser expresso pelo operador modal deôntico, não se deve, em grego me dei, que é uma necessidade mais fraca, uma necessidade que comanda, sim, mas não impossibilita contrafatos. Ora, uma tal necessidade é, não o é impossivel da Lógica formal, mas sim o não se deve da Ética. O Princípio de Não-Contradição não diz que é impossível dizer ou escrever uma contradição, diz apenas que não devemos fazê-lo, que a contradição deve ser evitada. Apel não precisaria, como que num malabarismo intelectual, fundamentar o Dever-ser através de uma contradição performativa de quem simultaneamente afirma e nega o Princípio $\mathrm{D}$; bastaria explicitar algo que ele sempre diz e repete quando formula o Princípio de Não-Contradição como o Princípio da Contradição a Ser Evitada (das Prinzip des zu vermeidenden Widerspruchs). Quando, muitos anos atrás, numa conferência em Frankfurt, expus a fundamentação do Dever-ser através de uma formulação corrigida do Princípio de NãoContradição, Apel falou: "Mas isso eu sempre disse". Ele tem toda a razão. Todo o mundo, desde Aristóteles, sabia disso. Só que a formulação errônea do grande Aristóteles, que usou um operador modal forte demais, prevaleceu e isso obnubilou as mentes de todos nós por dois mil e quatrocentos anos. A fundamentação primeira do Dever-ser que é a base de uma Ética Geral consiste em algo que é conhecido e aceito por todos, consiste no Principio da Contradição a Ser Evitada: Não se deve predicar e não predicar o mesmo predicado do mesmo sujeito sob o mesmo aspecto e ao mesmo tempo. De onde vem o Dever-ser? Como se justifica?

20

Cd. ARISTÓTELES, Meta. 1005 b 20. 
Como se fundamenta? Como sempre todos os filósofos o fizeram, sem se dar conta disso, através do Princípio de Não-Contradição. É simples, é óbvio, é aceito por todos. Mas ninguém até hoje havia dito o simples e o óbvio: O Dever-ser da Ética Geral está lá no começo de tudo, inclusive da Lógica, na formulação do Principio de Não-Contradição. A Não-Contradição é um principio ético. O Primeiro Princípio de todo pensar e falar, de toda racionalidade, segundo Aristóteles, só possui validade universal e só está corretamente formulado, se é formulado com o operador modal deôntico: Dever-ser.

E o Princípio de Não-Contradição em sua formulação clássica, com o operador forte, é impossivel, não possui validade? Claro que sim. Mas sua validade não é universal como a do princípio formulado com operador deôntico, e sim restrita ao mundo particular dos sistemas lógicos livres de contradição. Em tais sistemas melhor seria chamá-los de subsistemas - não há contradição nunca. Neles a contradição é impossivel; impossível no sentido técnico forte. O Princípio de NãoContradição que é o primeiro princípio e fundamento da Primeira Filosofia, este é um princípio deôntico, com operador mais fraco, que não torna contrafatos algo impossivel. Eis, aqui, em sua singela simplicidade mas também em sua força e grandeza, o argumento de fundamentação do Dever-ser $e$, assim, do primeiro principio de uma Etica Geral.

Năo fizemos a passagem de uma proposição descritiva para uma proposição normativa. Considero isso um falso problema, pois o reino das proposiçōes normativas é um conjunto maior dentro do qual está o conjunto das proposiçōes meramente descritivas, que são tais, ou seja, apenas descritivas, porque foram objeto de um recorte, de uma abstraçăo, de um processo de empobrecimento. Fizemos o quê? Mostramos que o Primeiro Principio, universalíssimo e válido para tudo sem exceçăo, o Principio de Năo-Contradiçāo, se e quando corretamente formulado, já é uma proposiçāo normativa e expressa um Dever-ser.

O Princípio de Não-Contrađição precisa ser ulteriormente justificado? Pode ser ulteriormente justificado? Já Aristóteles dizia: somente de forma indireta. Quem o nega, ao negá-lo, está de novo a pressupô-lo. O Principio de NãoContradiçäo, quando negado, renasce das cinzas de sua própria negaçäo. Esta é a verdadeira e ampla contradição performativa, descoberta por Platão e Aristóteles, redescoberta em nossos dias numa formulaçăo mais estreita por Apel e Habermas. Significa isto, que o primeiro princípio de toda nossa racionalidade não pode ser justificado? Não, significa que o princípio é tão amplo e universal como a própria racionalidade e, sendo assim, não pode ser demonstrado por algo que the seja externo e anterior, por algo que esteja fora dele. Então, perguntará Hans Albert," pondo-nos face ao Trilema de Münchhausen, é Dogmatismo? Não, em absoluto. Trata-se de circularidade, de boa circularidade, de um processo circular de autojustificação. Sabe-se que esta circularidade especifica é boa circularidade, porque seu contránio é uma má circularidade. Quem nega o Principio de Não-Contradiçăo entra em autocontradição e repöe o que quer negar. O Trilema de Münchhausen

"t ALBBRT, H., Traktat uber knitische Vemunft, 5.ed., Tubingen: Mohr, 1991; cf. também ALBERT, H. Transzendentale Träumerelen. Karl Otto Apels Sprachspiele und sein hermeneutischer Gott, Hamburg: Hoffmann/Campe, 1975. 
com suas três pontas só é problema para quem não é dialético, para quem pensa erroneamente ${ }^{22}$ - que toda circularidade é sempre má circularidade.

Há, nessa argumentação, algum vestígio de falácia naturalista? Certamente que não. Não estamos partindo de uma natureza dada, não estamos pressupondo nenhuma Ontologia específica, não estamos pressupondo uma proposição descritiva ou normativa qualquer; não estamos nem mesmo pressupondo um fato da razão. Estamos apenas corrigindo o operador modal do Princípio de NãoContradição de modo que este cumpra sua função de primeiro princípio e possua realmente validade universal. Não há falácia naturalista, porque bem no começo de nossa argumentação - e durante todo o transcurso da mesma - só falamos do Princípio da Contradição a Ser Evitada. No começo de todo e qualquer processo de justificação racional está a Lógica e o primeiro princípio da Lógica é um princípio ético, com operador deôntico, o da Contradição a ser Evitada. A natureza vem depois da Lógica; e só depois da natureza é que vem a Ética tradicional, aquela que diz o que o homem deve ou não deve fazer em determinadas circunstâncias. Muito antes disso, antes da Ética no sentido tradicional, antes da Filosofia da Natureza, vem a Lógica. Bem no começo da Lógica, no entanto, o primeiro princípio é de caráter deôntico. Esta Ética, a Ética grande e abrangente, perpassa toda a Filosofia - Lógica, Natureza e Espírito - desembocando, em seu final, em Ética no sentido tradicional, em Estética e em Filosofia da História. Quem, bem no começo da Lógica, diz não se deve predicar e não predicar o mesmo predicado do mesmo sujeito sob o mesmo aspecto e ao mesmo tempo, está formulando - em termos lógico-lingüísticos - o primeiro grande princípio de toda a Filosofia, que é o grande princípio ético.

Concedido que o operador modal do Princípio de Não-Contradição seja deôntico, está também concedido que foi feita uma justificação radical do Dever-ser. Mas isso pode ser chamado de Ética? Moral? Sittlichkeit? Esta formulação do Princípio de Não-Contradição fala apenas do uso correto de sujeitos e de predicados; isso pode ser formulado e interpretado como um princípio que vá reger as ações dos homens em suas relações intersubjetivas? O que o uso correto de predicados tem a ver com a eticidade de nossas ações? Com a Ecologia? Não há uma distância enorme entre um ponto e o outro? Esta distância tem que ser vencida, isso tem que ser mostrado. Mas, fiquemos avisados, para isso é preciso pensar grande. Grande como Platão, como Espinosa, como Hegel. O quadro estreíto em que os éticos contemporâneos geralmente se movimentam não permite que a cadeia do raciocínio de desenvolva e faz o argumento definhar. Abramos $\vec{s}$ pois, os horizontes.

\section{O princípio da coerência na lógica, na natureza e no espírito}

O sistema da Filosofia começa com a Lógica que é, ao mesmo tempo, uma Ontologia. O começo tem que ser uma Lógica, pois bem no começo, ou falando de forma mais dura ainda, junto com o começo, tem que ser feita uma justificação

22 Cf. CIRNE-LIMA,C., Dialética e liberdade - Razões, fundamentos e causas, Veritas 43 (1998) p.795816. 
deste começo, que é o princípio - no sentido de começo - de todo o processo, bem como dos princípios - agora no sentido de regra - que regem o curso do processo do pensar e do falar. Isto significa que todo começo, em Filosofia, tem que se flectir sobre si mesmo, tem que ser circular: o pensamento, que coloca a questão filosófica sobre o sentido das coisas e do. Universo, tem que primeiro refletir sobre si mesmo, trazer à luz as regras que o constituem e, num processo circular de autojustificação, fundamentar a racionalidade destas regras. Isso é Lógica, não Lógica formal no sentido moderno, mas Lógica no sentido de Hegel. Esta Lógica, ao trazer à luz os primeiros princípios ou regras que constituem o pensar, imediatamente coloca a questão, se estas regras são apenas regras do pensar ou são também regras do ser. Esta Lógica é também uma Ontologia? Os nexos necessários que travejam o pensamento são também relações necessárias existentes no mundo das coisas? Os primeiros princípios de uma gramática profunda do pensar e do falar são também os primeiros princípios da gramática do ser? Sim, necessariamente. Se eles não fossem também princípios do ser, ou não seriam os primeiros princípios do pensar, ou, pior ainda, não existiria entre pensar e ser nenhuma - repito com ênfase - nenhuma coerência e/ou correspondência, o que significa que não existiria verdade em nosso pensar e falar. Ora, levantamos, quando falamos, pretensões de verdade: há proposições que são verdadeiras. Logo, ao menos os primeiros princípios do pensar e do falar são também princípios do ser. Mesmo que as regras ulteriormente derivadas sejam diferentes na Lógica e na Ontologia, os primeiros principios de uma Lógica, que se queira filosófica, são também os primeiros princípios de uma Ontologia. Essa conexão básica entre Lógica e Ontologia, Platão a sabia e afirmava, Aristóteles a confirmava, Hegel a reconstruiu, todos os grandes filósofos da tradição a defenderam. Desde Platão até o primeiro Wittgenstein esta era a doutrina comum, negada apenas por alguns céticos radicais, como Górgias, e alguns dentre os nominalistas.

Trata-se, pois, numa primeira etapa, de mostrar e justificar, num movimento circular de autoflexão, os primeiros princípios que regem o pensar e o falar. Numa segunda etapa, há que se mostrar que os mesmos principios, já justificados na Lógica, são também princípios do ser, isto é, da Ontologia e da Filosofia da Natureza.

Aristóteles e nós com ele afirmamos que o primeiro princípio tanto do pensar como do ser é o Princípio de Não-Contradição. Esta afirmação está correta, mas neste enfoque muito abstrato o tema, que em si já é difícil, fica por demais complexo. Por isso, ao invés de falar de um único princípio, o de Não-Contradição, como Aristóteles, façamos como Platão e falemos de dois princípios, o Uno e a Diade, tò hén e aónistos dyás. Ou, de forma mais didática ainda - mas sempre dizendo, no fundo, a mesma coisa que Platão - falemos de três primeiros princípios do pensar e do ser, sabendo que o primeiro e o segundo deles, que são tese e antítese, se fundem e unificam no terceiro, que é a sintese. $O$ primeiro princípio é o da Identidade, o segundo é o da Diferença, o terceiro é o da Coerência. Estes três princípios, no fundo, são um só princípio, o da Coerência Universal, pois a síntese contém em si, superadas e guardadas, tanto tese como antítese. 
O Princípio da Identidade versa sobre a identidade simples, a identidade iterativa e a identidade reflexa. A identidade simples é tão simples que não pode ser ulteriormente determinada. Quem diz uma palavra ou escreve um signo está exercendo a identidade simples. Identidade simples é, por exemplo, $A$. Nada mais é dito nem pensado, $A$, apenas $A$. A identidade iterativa, um operador de suma importância, ocorre quando o $A$ se repete, e se repete, e se repete de novo, e assim ad infinitum. Identidade iterativa é dizer $A, A, A$... Identidade reflexa emerge quando dizemos que $A=A$. O A, flectido sobre si mesmo, se descobre idêntico a si mesmo. Isto já é reflexão. Estas três formas de identidade são o chão do qual irão brotar, mais tarde - quando forem introduzidos sinais de constantes e variáveis e os primeiros operadores lógico-formais - as assim chamadas Lógicas da Identidade. O Princípio da Identidade não pode ser demonstrado, pode apenas ser mostrado, como o foi acima. Uma demonstração pressuporia que existiria algo antes dele, o que não é o caso. $O$ verdadeiro princípio não pode ser objeto de justificação, ele se autojustifica de maneira circular. Quem afirma o contrário entra sempre em autocontradição. Alguém negou, por acaso, durante a longa história de nossa tradição, a verdade de proposições tautológicas?

O Princípio da Diferença versa sobre a emergência do novo, daquilo que é diferente, daquilo que não está contido nem no $A$ da identidade simples, nem na série $A, A, A \ldots$ da identidade iterativa, nem no $A=A$ da identidade reflexa. $O$ Princípio da Diferença explica e faz surgir um $B \operatorname{um} C$, um $D$, e assim por diante, algo que não está pré-programado pelo Princípio da Identidade, algo de novo, de diferente, que não está ínsito de maneira seminal na Identidade, e por isso não pode ser dela derivado a priori. O Princípio da Diferença é o chão do qual, mais tarde, brotarão o conceito de contingência, de liberdade e de historicidade. Sem a diferença só existiria a Lógica formal, um mundo no qual tudo o que é possível é sempre também necessário; um mundo no qual não há existência, no qual não existem nem as coisas contingentes nem sua história. Este Princípio da Diferença não pode ser negado sem contradição performativa, pois os próprios atos de pensar e de falar através dos quais mais acima falamos e escrevemos sobre o Princípio da Identidade não são algo apenas lógico; os atos do pensamento e os atos de fala, mesmo quando versam sobre temas meramente lógico-formais, são sempre algo existente no mundo real das coisas contingentes, eles próprios existem contingente e historicamente. A Lógica, em seu conteúdo, é necessária e etema; os atos de pensar do homem que faz Lógica - e sem os quais a Lógica não estaria sendo aqui discutida - são contingentes e históricos.

$O$ terceiro princípio é o Princípio da Coerência. A questão da coerência surge somente após a emergência de um $B$, ou de um $C$, etc. Tendo em vista a Identidade do $A$, da série iterativa de $A, A, A \ldots$ e da identidade reflexa $A=A$, o que ocorre quando há a emergência de um $B$ que é, pelo menos inicialmente, o $B$ é completamente diferente do $A$ e não está nele contido. Pode ser que haja incompatibilidade, isto é, pode ocorrer que $A$ exclua $B$, ou que $B$ exclua $A$. Nestes casos o Princípio de Coerência simplesmente elimina um dos dois pólos contrários. Assim a verdade de uma proposição $A$, universal afirmativa, implica que a proposição contraditória $O$, particular negativa, seja falsa. A verdade de um pólo, nestes e 
em outros casos análogos, anula e elimina seu pólo oposto. A verdade da proposição $A$ implica a falsidade da proposição $O$. Coerência, pois, num primeiro subprincípio, significa destruição e eliminação. Em Lógica, isso é chamado de falsidade; se a proposição é falsa, a pegamos e jogamos fora. Há ainda um segundo subprincípio da coerência. Existem casos em que a emergência do novo, do diferente, não leva à eliminação de um dos pólos opostos e sim à operaçäo lógica de fazer as devidas distinçōes. Através da construçāo, no discurso lógico, das devidas distinções, ao invés de eliminar um dos dois pólos em conflito, conciliamos os pólos que antes estavam em oposição excludente, de forma que agora, face às devidas distinçōes, ambos os pólos antes opostos ficam conciliados. Assim, as proposiçōes Sócrates é menor que $1,60 \mathrm{~m}$ e Sócrates é maior que $1,60 \mathrm{~m}$ num primeiro instante estão em oposiçắo e se excluem mutuamente. Mas os pólos opostos se conciliam tão logo fazemos, através de proposições reduplicativas ou explicativas, as devidas distinções: Sócrates, enquanto está sentado, é menor que 1,60m, Sócrates, enquanto está de pé, é maior que $1,60 \mathrm{~m}$.

Neste lugar, exatamente aqui, a Lógica se bifurca em Lógica analítica e Lógica dialética. A Lógica analítica usa sempre um sujeito lógico expresso e é nele que ela faz as devidas distinções. Como no exemplo acima de Sócrates. A Lógica Dialética tem como sujeito lógico sempre o Absoluto, mas este sujeito nunca está expresso, é um sujeito oculto. Assim, estando o sujeito lógico sempre oculto, os Dialéticos não podem conciliar os opostos através das devidas distinçōes a serem feitas no sujeito. Daí a maneira dialética de, ao invés de fazer as devidas distinções, "superar e guardar" os opostos através da introdução de um novo predicado, no qual os pólos antes conflitantes estejam, já agora, conciliados. O sujeito oculto, o Absoluto, continua sempre o mesmo. As diferenciações, ou seja, as devidas distinções ocorrem só através da tematização de novos predicados.

Observemos que o Princípio da Coerência é, no fundo, o Princípio de NăoContradiçăo formulado por Aristóteles. Ele diz que näo se deve afirmar e negar o mesmo predicado do mesmo sujeito sob o mesmo aspecto. Se não se pode distinguir aspectos, um dos pólos - o falso - deve ser eliminado. Se queremos ser racionais e levantar pretensão de verdade, devemos segurar o pólo certo e jogar fora 0 pólo falso. Ou, então, se for possível fazer as devidas distinçōes, devemos fazê-lo para que o discurso, sem perder sua racionalidade, se enriqueça. Isso pode ser feito à maneira analítica, através de distinções apostas ao sujeito lógico expresso, ou à maneira dialética, através da escolha de um novo predicado que sintetize e concilie os pólos antes excludentes.

Estas operaçōes para restabelecer a coerência que foi posta em cheque pela emergência de algo novo e diferente se constituem num Dever-ser. Todo Deverser manda, comanda, determina, mas não torna contrafatos algo impossivel. Quem näo obedecer ao Dever-ser expresso no Princípio da Coerência, quem disser contradições, não está só por isso morto e eliminado do Universo. Não, quem se nega a obedecer ao Princípio da Coerência está dizendo bobagens, será tratado como bobo; um tal falante, ao dizer sempre se desdiz. Ele não é reduzido ao estado de planta, como queria Aristóteles, porque esta não fala e já por isso não diz bobagens. Quem, em Lógica, se contradiz continua existindo, dizendo e se desdi- 
zendo, é um tolo que se colocou fora de toda e qualquer racionalidade. Isso não deve ser. Mas que pode acontecer, pode; isso de vez em quando existe. Coerência, em Lógica, é algo que deve ser, mas isso não significa que a incoerência seja algo impossível. Aristóteles tinha toda razão; seu único erro foi ter usado um operador modal forte demais. Assim, formulado como acima fizemos através do operador deôntico, o Princípio de Coerência sintetiza dentro em si a identidade e a diferença, concilia ambas, e garante que, quem a ele obedecer, continuará racional e compreensível, sem que o conflito de pólos mutuamente excludentes o jogue num mundo em que não há mais nenhuma razão e no qual nada faz sentido. $O$ que foi exposto acima mostra que o grande princípio da Lógica, o Princípio da Coerência, é um princípio ético: o Princípio da Contradição a Ser Evitada.

Na Natureza, isto é, na Ontologia e na Filosofia da Natureza, vigem os mesmos três Princípios, o da Identidade, 0 da Diferença e o da Coerência. Isso à primeira vista parece estranho, pois estes termos possuem uma conotação lógicoontológica que dificulta sua compreensão por parte dos cientistas da Natureza. Mas basta traduzi-los para a terminologia das Ciências Naturais - falo só de Biologia porque meus conhecimentos de Física são por demais precários - para que se perceba, sem nenhuma ulterior demonstração, que os mesmos três grandes princípios que regem a Lógica regem também a Natureza. Também aqui não é preciso demonstrar, basta mostrar. Veremos que aquilo que parecia ser apenas uma teoria de Lógica é também a grande teoria da Natureza, isto é a teoria geral da evolução tal como Empédocles, Darwin e os biólogos contemporâneos a formulam e defendem. Basta olhar e verificar a correspondência entre os termos expressos na linguagem da Lógica e os termos expressos na terminologia da Ciência da Natureza.

\section{PRINCIPIOS DA LOGICA}

\section{Identidade}

- simples A

- iterativa A, A, A ...

- reflexa $A=A$

II. Diferença

o novo, o diferente

\section{Coerência}

- eliminação de um dos pólos

- fazer as devidas distinções

\section{PRINCIPIOS DA NATUREZA}

o individuo
replicação e reprodução
espécie

emergência do novo, mutação por acaso

$$
\begin{aligned}
& \text { morte }=\text { seleção natural } \\
& \text { adaptação }=\text { seleção natural }
\end{aligned}
$$

Percebe-se, de imediato, pela correspondência que há entre as duas colunas, que se trata da mesma teoria formulada, na coluna à esquerda, em termos de Lógica, e expressa, na coluna à direita, em terminologia das Ciências da Natureza, especificamente da Biologia. A teoria que levantamos mais acima para explicar e justificar o primeiro princípio de uma Lógica fundada no Dever-ser é, ela mesma, a mesmíssima teoria, também uma Teoria Geral da Evolução. 
A Teoria Geral da Evolução, atribuída por Aristóteles a Empédocles, ${ }^{23}$ diz qué o indivíduo existe, ou seja, é identidade simples, um $A$. Diz depois que este indivíduo entra num processo iterativo, que em Biologia molecular se chama replicação, em Biologia geral, reprodução. $O$ indivíduo, que se replica ou reproduz, ao fazê-lo, engendra outros indivíduos iguais a ele mesmo: $A$., $A, A$... Aquilo que é comum a dois ou mais indivíduos, distintos enquanto indivíduos, mas iguais em sua estrutura qualitativa, chama-se espécie, $A=A$. A unidade da espécie contém, dentro em si, a pluralidade de indivíduos.

Mas se fosse só isso, se não surgisse nunca nada de novo, não existiria a variedade de seres e de formas de vida que vemos no mundo real. Mas esta variedade existe como fato. De onde ela surgiu? Do segundo grande princípio, do Principio da Diferença, em Biologia de hoje, da ocorrência de mutações por acaso.

E estas mutações são boas? Em que relação elas estão com a série reprodutiva de indivíduos, na qual elas surgem? Elas podem estar em coerência ou em incoerência com a série que se itera e reproduz. Coerência e incoerência são o objeto do terceiro grande princípio, do Princípio da Coerência. Havendo incoerência entre o indivíduo portador da mutação e o meio ambiente, que neste caso uma construção mental - são todos os outros indivíduos existentes, temos, como na Lógica, duas hipóteses. Ou a Natureza elimina um dos pólos, deixando-o morrer, ou os dois pólos, primeiramente em conflito, são conciliados através do engendramento de novos aspectos reais, de novas dobras, de novos comportamentos; neste caso, ao invés de morte, temos adaptação. O jogo, sempre de novo iterado, de mutações que são ou não são coerentes (isto é, adaptadas) e a morte das não coerentes (as não aptas), chama-se em Biologia de seleção natural e se constitui, como sabemos, no grande mecanismo que rege a gênese, a reprodução e também a ordem dos seres dentro da coerência que vige no Universo. ${ }^{24}$ Seja-me permitido chamar a atenção para o caráter deôntico do princípio de seleção natural, isto é, do Princípio de Coerência enquanto aplicado à Natureza. O princípio não diz que as mutações más não vão surgir nunca, o princípio não as torna impossíveis. Não, também aqui, na Natureza, o Princípio de Coerência é deôntico, isto é, ele permite contrafatos: surgem mutações que não são boas, que não estão em coerência, que não são aptas para sobreviver. O Princípio de Seleção Natural não diz que tais mutações são impossíveis; não, ele é deôntico e permite contrafatos. Só que, ao depois, ele entra em ação e, constatada a incoerência, ele pune com definhamento, doença e morte tudo que for incoerente, ou seja, tudo que não conseguir se adaptar dentro da coerência universal da Natureza. Na Lógica, exis-

23 A primeira formulação de uma Teoria Geral da Evolução, Aristóteles a atribui a Empédocles. Cf. ARISTOTELES, Physica, ed. cit., livro II, cap. 8, 198 b 29-32: "Nos casos em que o acaso produziu uma combinação como a que teria sido produzida de caso pensado (de propósito), tais criaturas, é dito, tendo sido bem formadas por obra do acaso, então elas sobrevivem; em caso contrário, eles pereceram e ainda perecem, como Empédocles diz de seus homens com cara de boi." Eis aqui, já nos pré-socráticos, em Empédocles, a Teoria Geral da Evolução e uma primeira formulação do prinć́pio de seleção natural. Impossivel ser mais claro e mais conciso. Aristóteles rejeita a Teoria da Evolução, que ele tão bem resume e expōe, porque não compreende e não aceita que o acaso possa funcionar como princípio de ordem. selfish gene, Oxford: Oxford Un.Press, 1976; idem, The Blind Watchmaker, London: Norton, 1987. 
tem de fato contradiçōes; devemos acabar com elas, ou por eliminação ou fazendo as devidas distinções. Na Natureza, existem mutações incoerentes com o todo maior no qual elas se inserem; estes mutantes ou săo eliminados pela morte ou săo premiados por serem adaptaçōes bem sucedidas. Tanto na Lógica como na Natureza năo existe a impossibilidade de contradições, respectivamente de mutaçōes incapacitantes. O operador, em ambos os casos, é deôntico. Ble permite contrafatos, só que, ao depois, a posteriori, num processo que se faz passo a passo no tempo histórico, o Princípio de Coerência ou elimina e mata ou transforma e adapta. Assim surge a multiplicidade de categorias filosóficas e a multiplicidade de seres no Universo real. Tanto na Lógica como na Natureza, o Princípio de Coerência nāo torna os absurdos algo impossivel, diz apenas o que deve acontecer com eles: eliminação das proposiçöes falsas, em Lógica, definhamento, doença e morte, na Natureza, ou entāo a feitura das devidas distinçōes, em Lógica, a adaptaçăo, na Natureza. Há, pois, também na Natureza, um Dever-ser, um principio que năo torna o contraditório algo impossivel, mas diz o que deve ser feito com ele. Em Lógica, as devidas distinçôes, na Natureza, as adaptaçôes. Se isso não ocorrer, o Princípio da Coerência, em ambos os reinos, na Lógica e na Nature$\mathrm{za}$, elimina e joga fora.

No reino do Espírito, isto é, daqueles seres vivos que, capazes de flectir-se sobre si mesmos se reencontram consigo mesmos em uma autoconsciência que é universal, aqui também vigem os mesmos três princípios, o da Identidade, o da Diferença e o da Coerência. Também o homem, o animal racional, ou seja, o animal que, sem deixar sua individualidade, consegue pela reflexăo ser e ver a Totalidade da qual ele é parte, também o homem, sujeito racional, é regido em suas relações intersubjetivas pelos três grandes principios que regem a Lógica e a Natureza. O homem, que é Espírito, como síntese que é, contém dentro em si, superadas em sua unilateralidade mas guardadas em suja riqueza, tanto a Lógica como a Natureza. O homem, Espírito que é, é Lógica que se tornou Natureza, e vice-versa, Natureza que se transformou em Lógica. A vigência e validade dos três grandes princípios também no reino do Espírito, do homem, não precisa ser demonstrada, mas sim mostrada. Ao traduzir os termos das terminologias da Lógica e da Filosofia da Natureza para categorias das Ciências Humanas, a correlação vem à luz com clareza meridiana: o mesmo travejamento que molda a Lógica e a Natureza, determina também o homem. Só que agora, no Espírito, há consciência tanto do engendramento do novo, que em Ciências Humanas denominamos de decisão livre, de criatividade, de autodeterminação, como também a correspondente responsabilidade ética; esta é a consciência da coerência ou incoerência da decisăo livre com as outras decisỏes, as já passadas, que constituem esta pessoa na construção de sua liberdade, como também a coerência ou incoerência com os projetos futuros, com os outros homens - a começar pelos mais próximos - com todos os seres e com todas as coisas da Natureza e, finalmente, com todo o Universo. O homem, ao decidir livremente e engendrar, assim, pela diferença sua personalidade, pode e deve medir sua decisão e a consequência de seus atos através do padrão de medida que é dado pelo Princípio da Coerência: Estou, com esta decisão livre, em coerência comigo mesmo, com os outros, com a Natureza, com o Universo? 
O gráfico abaixo mostra a perfeita corresponde̊ncia, sempre sob a vigência dos mesmos três principios, entre Lógica, Natureza e Espírito.

PRINCÍPIOS DA LOGICA

\section{Identidade}

- simples A

- fterativa $A, A, A \ldots$

- reflexa $A=A$

\section{Diferença}

o novo, 0 differente $B$
PrINCIPIOS DA NATUREZA

individuo

replicaçăo, reprodução

espécie

emergència do novo, mutação por acaso
PRINCIPIOS DO ESPIRTTO

homem

familia, educaçäo

sociedade, cultura

criatividade do ato

livre, invençăo, arte

\section{Coerencia}

- eliminaçăo de um dos polos morte-seleção natural

o mal - quando há incoerència

- fazer as devidas distinções adaptação-seleçăo natural

Vê-se, claramente, que à identidade simples da Lógica corresponde, na Natureza, o individuo, no Espirito, o homem individual. $\grave{A}$ identidade iterativa da Lógica correspondem, na Natureza, os processos de replicaçâo (nivel de DNA) e de reprodução (nível de Biologia geral), no Espírito, a familia e os processos educativos, os quais, reproduzindo saberes e atitudes, constituem uma iteração cumulativa que, perdendo a má infinitude existente na não-consciência (expressa em Lógica pelos três pontinhos), se sublima como formação espiritual, como Bildung. A identidade reflexa da Lógica corresponde, na Natureza, a unidade da espécie que abarca muitos indivíduos que, como espécie, são iguais; no Espírito, a identidade reflexa se manifesta na unidade de uma sociedade e de uma cultura, nas quais o Eu individual se transforma em Nós, nas quais as decisōes individuais se transformam em decisరెes sociais, nas quais a vontade individual se transforma em vontade geral, dando, assim, nascença ao Estado e às leis.

O Principio da Diferença, que na Lógica explica por que existem mais coisas que uma simples tautologia, que na Natureza explica a gênese da multiplicidade de espécies, no Espirito explica o que, em verdade, é liberdade, a criatividade do livre-arbitrio. O homem, por seu ato livre, escolhe uma dentre as várias altemativas possiveis e engendra assim algo que antes era apenas uma possibilidade e que, agora, é uma realidade efetiva. Liberdade consiste na criatividade que se exerce quando, no livre-arbítrio, nos determinamos de uma forma especifica, e não de outras. Liberdade sempre é criatividade, às vezes, ela é invenção de formas completamente novas de ser do Espirito, muitas vezes elas se constituem em arte. So que estas decisőes, invençőes e artes podem ser tanto boas como más. Qual o critério que deve reger nossas decisōes livres? Evidentemente aquele que é expresso pelo Princípio da Coerência Universal. Bom é tudo aquilo que é coerente consigo mesmo, com seu melo ambiente imediato - os outros homens - e mediato - a Natureza - e, em última instância, com todo o Universo. Mau é aquilo que é incoerente em qualquer dos niveis acima citados. Tanto o Bem como o Mal se constituem como tais através da coerência ou da incoerência, ambas entendidas 
em seu sentido pleno, que do individual vai para o universal, e deste retorna àquele, num movimento de vai-e-vem que caracteriza e constitui tanto o indivíduo em seu bom sentido como o Universal Concreto que é o Universo. Mas, em casos do dia-a-dia, como saber se uma decisåo é coerente em todos esses niveis? Aí é preciso, primeiro, conversar consigo mesmo, para ver se há coerência interna. Logo depois, conversar com os homens ao meu redor, de minha familia e de minha sociedade, para ver se minha decisão pode ser por eles aceita sem prejudicálos. A seguir, devo ampliar essa conversa real, feita na roda do discurso de meu mundo real, de maneira que ela se transforme numa conversa na roda ideal do discurso, roda esta que abrange todos os homens, mais, todos os seres do Universo. A decisão é boa se e quando ela pode ser inserida harmoniosamente na rede de relações que constituem o Universo. A ação é eticamente boa se e enquanto ela possui, dentro em si, coerência universal. Má, se e quando não há coerência universal.

Vemos, de imediato, a semelhança entre a teoria proposta e a Ética do Discurso de Apel e Habermas. Certo, corretíssimo. Meu Princípio de Coerência, quando aplicado ao Espírito, é uma formulação do Imperativo Categórico de Kant, do Princípio U de Apel e Habermas. Só que minha proposta explica coisas que eles não conseguem explicar, como, por exemplo, as regras do bem viver (des guten Lebens), que eles confessam näo poder fundamentar e que eu fundamento de maneira bem simples através da coerência consigo mesmo, pensada - é claro como etapa do movimento que leva do Eu individual ao Eu que se sabe o Universo. Apel e Habermas não conseguem fundamentar a eticidade só com os princípios $\mathrm{D}$ e U, e dizem expressamente que tem que haver no discurso Gründe, razōes, que săo decisivas. Isso não obstante, não introduzem um terceiro Princípio, um Principio G (Gründe), sem o qual a Ética do Discurso não subsiste, por recair no formalismo vazio. Em minha proposta, desde a Lógica, passando pela Natureza e chegando ao Espíito, os grandes principios nunca são meramente formais, pois o segundo deles, o Principio da Diferença exige e garante que haja sempre um conteúdo material que é diverso tanto do formalismo da Identidade como de uma mera regra formal de Coerência. Muito pelo contrário, é exatamente o Princípio da Diferença que nos permite e obriga a ter um Princípio da Coerência que seja distinto do mero Princípio de Identidade. Mas, seja dito claro e expressamente, muito devo a Kant, a Apel e a Habermas; também eu uso e defendo o Imperativo Categónico e o Princípio da Universalização, mas não o utilizo como um princípio meramente formal ou procedimental. Para mim o Universal não é o universal abstrato com que lidam Kant e os kantianos, entre eles Apel e Habermas, e sim o Universal Concreto de Hegel.

\section{Respostas e conseqüências}

A grande objeção de Hegel contra a Ética de Kant é a de que o Imperativo Categórico é um princípio meramente formal que, enquanto tal, não só é vazio de conteúdos determinados mas - muito pior - admite qualquer tipo de conteúdo. As objeçőes de Hegel foram, de seu tempo até nossos dias, muitas vezes retomadas e reformuladas, de sorte que as objeçōes contra o formalismo em Ética e as muitas 
em seu sentido pleno, que do individual vai para o universal, e deste retorna àquele, num movimento de vai-e-vem que caracteriza e constitui tanto o indivíduo em seu bom sentido como o Universal Concreto que é o Universo. Mas, em casos do dia-a-dia, como saber se uma decisão é coerente em todos esses niveis? Aí é preciso, primeiro, conversar consigo mesmo, para ver se há coerência interna. Logo depois, conversar com os homens ao meu redor, de minha familia e de minha sociedade, para ver se minha decisão pode ser por eles aceita sem prejudicálos. A seguir, devo ampliar essa conversa real, feita na roda do discurso de meu mundo real, de maneira que ela se transforme numa conversa na roda ideal do discurso, roda esta que abrange todos os homens, mais, todos os seres do Universo. A decisaão é boa se e quando ela pode ser inserida harmoniosamente na rede de relações que constituem o Universo. A ação é eticamente boa se e enquanto ela possui, dentro em si, coerência universal. Má, se e quando não há coerência universal.

Vemos, de imediato, a semelhança entre a teoria proposta e a Ética do Discurso de Apel e Habermas. Certo, corretíssimo. Meu Princípio de Coerência, quando aplicado ao Espírito, é uma formulação do Imperativo Categórico de Kant, do Princípio U de Apel e Habermas. Só que minha proposta explica coisas que eles năo conseguem explicar, como, por exemplo, as regras do bem viver (des guten Lebens), que eles confessam não poder fundamentar e que eu fundamento de maneira bem simples através da coerência consigo mesmo, pensada - é claro como etapa do movimento que leva do Eu individual ao Eu que se sabe o Universo. Apel e Habermas não conseguem fundamentar a eticidade só com os principios $\mathrm{D}$ e U, e dizem expressamente que tem que haver no discurso Gründe, razōes, que são decisivas. Isso não obstante, não introduzem um terceiro Princípio, um Princípio G (Gründe), sem o qual a Ética do Discurso não subsiste, por recair no formalismo vazio. Em minha proposta, desde a Lógica, passando pela Natureza e chegando ao Espírito, os grandes principios nunca são meramente formais, pois o segundo deles, o Princípio da Diferença exige e garante que haja sempre um conteúdo material que é diverso tanto do formalismo da Identidade como de uma mera regra formal de Coerência. Muito pelo contrário, é exatamente o Princípio da Diferença que nos permite e obriga a ter um Princípio da Coerência que seja distinto do mero Princípio de Identidade. Mas, seja dito claro e expressamente, muito devo a Kant, a Apel e a Habermas; também eu uso e defendo o Imperativo Categórico e o Príncípio da Universalizaçäo, mas não o utilizo como um princípio meramente formal ou procedimental. Para mim o Universal não é o universal abstrato com que lidam Kant e os kantianos, entre eles Apel e Habermas, e sim o Universal Concreto de Hegel.

\section{Respostas e conseqüências}

A grande objeção de Hegel contra a Ética de Kant é a de que o Imperativo Categórico é um princípio meramente formal que, enquanto tal, não só é vazio de conteúdos determinados mas - muito pior - admite qualquer tipo de conteúdo. As objeçōes de Hegel foram, de seu tempo até nossos dias, muitas vezes retomadas e reformuladas, de sorte que as objeçōes contra o formalismo em Ética e as muitas 
tentativas de resposta continuam uma questão aparentemente em aberto. Menciono aqui, pela clareza da exposição, o livro clássico de G. Singer ${ }^{25}$ bem como os trabalhos de 0 . Guariglia ${ }^{26}$ sobre o problema da universalização como critério de Ética. Os defensores do formalismo, como Kant e os kantianos em geral, dentre eles também os defensores da Ética do Discurso, Apel e Habermas, afirmam que o critério último de eticidade consiste na possibilidade de universalização. Se uma ação pode ser universalizada, então, ela é ética. Assim, a mentira não pode ser universalizada, pois, se todos sempre e em todos os casos mentem, deixa de existir a mentira porque todos sabem que é sempre verdadeiro o oposto do que é dito. O matar não pode ser universalizado, porque então a humanidade simplesmente acabaria e não haveria mais quem matasse e quem fosse morto. $\mathrm{E}$ assim por diante. Em tais exemplos, que são os que Kant utiliza, e em alguns outros o critério da universalização parece funcionar. Mas à medida que passamos para outros exemplos de universalização o critério falha de maneira estrondosa. Como no caso do professor ou do padeiro. Se todos os homens se tomam professores, implode 0 conceito de professor, a própria figura do professor acaba, pois, se todos são professores, então não existe mais nenhum aluno, e sem aluno não existe professor. Se todos ficam padeiros, a humanidade e, com ela, todos os padeiros acabam, pois não existe mais quem plante, quem transporte, que produza outros bens e serviços necessários. Singer discute e analisa uma série de exemplos interessantes, Guariglia também. Poder-se-ia aqui responder que a universalização não consiste nisso. Não se trata, dir-se-ia, de pensar como possível que todos os homens fiquem professores ou padeiros, mas sim de pensar que todos os homens possam aceitar que alguns homens fiquem professores e outros fiquem padeiros. A universalização como critério de eticidade significaria apenas que todos os homens podem aceitar o fato de que alguns homens em determinadas circunstâncias possam agir de uma determinada maneira. Só que, nessa hipótese, já não temos mais um único grande princípio ético, o da universalização, e sim uma pluralidade de critérios específicos, ou seja, uma Ética Material de Valores, como queria Scheler, ${ }^{27}$ ou até uma Ética da Situação. Pois não se trata mais de um principio formal que possa ser aplicado a todo e qualquer caso, mas de razões particulares de homens individuais. A universalização pensada apenas como possibilidade universal de aceitação (= uma decisão ou ação pode ser aceita por todos os outros) conduz de novo à questão sobre o porquê, sobre um critério que nos diga como e por que uma ação pode ser aceita por todos. $O$ argumento, aqui, fica circular no mau sentido. As objeções de Guariglia contra Habermas mostram bem isso. E apesar de todas estas objeções continuamos com o vago sentimento de que Kant, Apel, Habermas e todos os demais kantianos, em alguma coisa, têm razão. Então, o que fazer? Fazer o quê?

25 Cf. SINGER, M.G., Verallgemeinerung in der Ethik. Zur Logik moralischen Argumentierens, Frankfurt am Main: Suhrkamp, 1975 (o original Generalizations in Ethics é de 1961).

28

GUARIGLIA, O ., Moralidad. Ética Universalista y Sujeto Moral, Buenos Aires: Fondo de Cultura Económica de Argentina, 1996; idem, Ideologia, Verdad y Legitimacion, Buenos Aires: Fondo de Cultura Económica de Argentina, 1993.

${ }^{27}$ SCHELER, M., Der Formalismus in der Ethik und die materiale Wertethik, Bern/München, 1980 (a primeira edição é de 1913/16). 
O erro cometido por Kant e pelos kantianos, por Apel e Habermas, consiste a meu ver - em pensar o Princípio de Universalização como um universal abstrato como todos nós, depois do nominalismo de Ockham, o fazemos. O universal, pensado assim, é uma classe e, ao contrário das idéias platônicas e das formas aristotélicas, é um constructo lingüístico, um fruto da criação coletiva, e é, por isso, algo arbitrário. Hoje sabemos que um conceito universal - neste sentido contemporâneo do termo - possui sentido conforme seu uso; o uso define, assim, o universal. O princípio de universalização, entendido desta forma, como universal abstrato, não leva a um critério universal do Dever-ser que seja defensável, porque Universal tomado nesse sentido significa sempre algo particular, histórico, contingente, pertencente a uma determinada cultura.

O panorama muda completamente se tomamos o Princípio de Universalização e/ou o Imperativo Categórico não como um universal abstrato mas como o Universal Concreto. O Universal Concreto, termo típico da filosofia de Hegel mas já prefigurado em toda a tradição neoplatônica, significa não um fingimento da mente, mas algo existente no mundo real e concreto. Assim - exemplos de Hegel - a familia, a sociedade e o Estado são formas de Universal Concreto. Eu acrescentaria: a linguagem falada por um povo é um Universal Concreto; uma passeata de grevistas protestando contra o fechamento de uma fábrica e gritando, em uníssono, palavras de ordem, os hinos cantados em cantochão pelos monges de uma abadia medieval, os movimentos de ordem unida exibidos por um grupo de elite de fuzileiros navais, tudo isso são universais concretos, nos quais o indivíduo como que desaparece, ficando no primeiro plano apenas aquele Todo maior, real, existente, concreto, visível, ordenado. O Universal Concreto em seu sentido pleno é - nisso sigo fielmente Hegel - o Universo. Se falamos do Princípio de Universalização no sentido no Universal Concreto, então ser universal significa, não o fato de poder ser subsumido em um conceito abstrato ou classe, mas sim o fato de inserir-se harmoniosamente ou não harmoniosamente naquele Todo que é o Universo. Se universalização for pensada assim, isto é, como inserção harmoniosa no Universo, então ela é realmente um critério de eticidade e coincide exatamente com o que mais acima chamamos de Princípio de Coerência Universal. Assim como um pistão de motor de automóvel não pode ser inserido harmoniosamente num relógio de pulso, assim também certas decisões e ações não podem ser inseridas harmoniosamente numa familia, numa sociedade, num estado e, em última instância, no Universo. Este, sim, é o critério último de eticidade: a universalização entendida como possibilidade de inserção harmoniosa na Totalidade, camada por camada, através de todas as mediações, até chegar ao Universal Concreto que é o Universo. Este é o terceiro princípio de meu projeto de sistema, o Princípio da Coerência Universal. Ele difere do Imperativo Categórico de Kant e do Princípio U de Habermas porque o Universal nele não é abstrato mas sim concreto.

Vê-se de imediato que as objeções usualmente feitas contra o formalismo de Kant e dos kantianos não atingem a solução proposta. Não se trata de que todos os homens possam ficar professores ou padeiros; não se trata também de uma afirmação - infundada, aliás - de que todos os homens possam aceitar o fato de 
que alguns homens querem ser professores e padeiros. Trata-se da explicação que diz por que todos os homens podem aceitar tais coisas: pode ser aceito por todos aquilo e somente aquilo que está em coerência universal. O Princípio da Coerência Universal diz o porquê, explica a razão pela qual podemos ou não podemos fazer, na roda do discurso, a universalização.

A roda do discurso, proposta na Ética do Discurso, perdeu um pouco de sua importância; entretanto, não foi descartada. Muito pelo contrário. Como podemos, sem o discurso real na roda real e ideal do discurso, descobrir como trazer à luz eventuais incoerências que muitas vezes estão só implícitas? Como desmascarar incoerências que fingem ser coerentes? A roda do discurso continua indispensável. Neste ponto estou de pleno acordo com Apel e Habermas. Minha divergência está no fato de que a Coerência Universal, como a penso, perpassa todo um sistema, Lógica, Natureza e Espírito; isto Apel e Habermas não aceitam de maneira alguma. Habermas disse, com muita elegância, que meu projeto é por demais ambicioso (zu ehrgeizig). ${ }^{23}$

Em compensação, exatamente por ser ambicioso, por ser abrangente, o projeto aqui apresentado consegue dar uma fundamentação sólida à Ecologia, o que é um desideratum que praticamente ninguém consegue satisfazer. Não devemos lançar lixo e detritos químicos num rio não apenas porque mais abaixo há outros homens que querem beber água, mas também pela simples e importante razão de que estamos ferindo a ordem da Natureza. Temos obrigações éticas para com a natureza, diretas e imediatas, mesmo que não haja outro homem envolvido. Isso deriva do Princípio de Coerência Universal. Apel, Habermas e os éticos contemporâneos em geral, têm enorme dificuldade de enraizar a Ecologia na Ética, porque a eticidade, para eles, é somente uma relação de homem para outro homem ou outros homens; a Natureza só entra nessa relação como algo intermediário. Isso evidentemente transforma a Ecologia em seu contrário, pois a Natureza só é pensada como meio, nunca como fim em si mesmo. É por isso que, em conseqüência dessa postura, os ecólogos são às vezes tratados como a bondade condescendente mas cautelosa com que se trata um louco manso. Numa Ética da Coerência Universal, a Ecologia é algo extremamente importante, como prática, mas algo totalmente óbvio e sem problemas, como teoria.

Outra conseqüência muito relevante da Ética Geral que está sendo aqui proposta é que nela existem tanto a recompensa como o castigo. Recompensa e castigo não são algo que cai do céu, como um Deus ex machina, na Pedagogia e no Direito. Não. Já na Ética existem, em sua forma primeira e primeva, recompensa e castigo. Recompensa é a própria coerência; quem é coerente e age coerentemente é alguém, só por isso, feliz e tranqüilo. Esta felicidade tranqüila de quem é coerente é a primeira e mais importante das recompensas; os pensadores medievais chamavam isto de paz da consciência. A incoerência, pelo contrário, significa sempre oposição, conflito, luta e, em última instância, infelicidade. Estar feliz, a eudaimonía de Aristóteles, é ser e estar coerente com o Universo. Quem não está

28 Comunicação verbal, Stamberg, 1995. 
coerente, seja consigo mesmo, seja com qualquer das instâncias mediadoras, nāo está coerente com o Universo e, só por isso, já é um infeliz, mesmo que aparente nāo saber. Quando, entảo, na Pedagogia e no Direito as categorias de recompensa e de castigo forem utilizadas, pode-se e deve-se dizer que elas foram elaboradas e justificadas na Ética Geral.

A Ética aqui proposta é uma ética evolucionista, pois entende o homem e o Universo como um processo em evolução. Isso não levaria a uma ética desumana, a uma ética sem dó nem piedade? Uma tal ética evolucionista não afirma, em última análise, que é o mais forte que tem razăo? A pergunta é perfeitamente cabivel, especialmente porque sabemos que as éticas evolucionistas geralmente

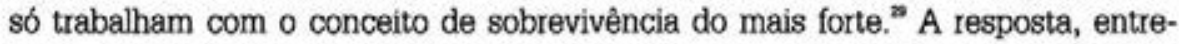
tanto, à questão feita é simples e singela: Ponhamos na Teoria Geral da Evolução o termo correto, ou seja, ao invés de falar do mais forte, falemos do mais coerente, e, expressamente, de coerência com todo o Universo, e as objeções usuais desaparecem como que por encanto. Pois năo é o mais forte, no sentido brutal do termo, que está certo e sobrevive, e sim o mais coerente, aquele que é coerente com todo o Universo.

Ct. a linguagem já mais moderada de Michael Ruse, RUSE., M., The significance of evolution, in: SINGER.P. (odit), A Companion to Bthics, Cambridge Mas.: Blackwell, 1993, p. $500 s 8$. 